\title{
Phytochemical Profile and Qualification of Biological Activity of an Isolated Fraction of Bellis perennis
}

\author{
Thiago H. Costa Marques ${ }^{1}$, Cassio H. Santos De Melo ${ }^{2}$, Rusbene B. Fonseca De Carvalho ${ }^{2}$, Luciana M. Costa ${ }^{1}$, \\ Alexandre A. De Souza2, Jorge M. David³, Juceni P. De Lima David ${ }^{3}$, Rivelilson M. De Freitas ${ }^{1, *}$ \\ ' Biochemistry and Pharmacology Department, Health Sciences Center, Federal University of Piauí, 64049-550 Teresina - PI, Brazil. \\ ${ }^{2}$ Chemistry Department, Natural Sciences Center, Federal University of Piauí, 64049-550 Teresina - PI, Brazil. \\ ${ }^{3}$ Organic Chemistry Department, Federal University of Bahia, 40170-115 Salvador - BA, Brazil.
}

\begin{abstract}
This study describes the isolation and identification of apigenin-7-O-glucopyranoside, a flavonoid isolated from the flowers of Bellis perennis L., Asteraceae, an species with a broad spectrum of biological activities. The in vitro antioxidant activity and the inhibition of the enzyme acetylcholinesterase were evaluated. The flavonoid showed strong in vitro antioxidant potential, because of the capacity of removal of hydroxyl radicals and nitric oxide, and also prevented the formation of thiobarbituric acid-reactive substances. These parameters were inhibited at the highest concentration of ApG at rates of $77.7 \%, 72 \%$ and $73.4 \%$, respectively, in addition to inhibiting acetylcholinesterase, suggesting potential use in the treatment of neurodegenerative diseases.
\end{abstract}

Key words: Acetylcholinesterase, Antioxidant, Bellis perennis, Flavonoid.

\section{INTRODUCTION}

The use of plants for the treatment and cure of diseases is as old as the human species; popular knowledge makes a major contribution to the dissemination of therapeutic virtues obtained from the use of these plants (Lubian et al., 2010). Many plants with biological potential can be highlighted among the various plant families, such as the family Asteraceae, which has approximately 1,620 genera and 23,600 species (Judd et al., 2009), including the genus Bellis and the species B. perennis, known as common daisy or English daisy.

Previous studies of flowers of $B$. perennis described the isolation of acylated oligosaccharides of oleanane-type triterpenes (Gudej, 2001), and also the use of B. perennis for its expectorant, healing, anti-inflammatory, antihemorraghic, anesthetic, antiparasitic, antifungal, antimicrobial and antioxidant properties (Avato et al., 1995; Oberbaum et al., 2005; Morikawa et al., 2008; Kavalcioğlu et al, 2010; Marques et al., 2011). A few authors suggest that the pharmacological and biological properties related to Alzheimer's disease, as well as the neuroprotective effect, inhibitory activity of acetylcholinesterase (AChE), antiallergic, antiviral, antiproliferative, antimutagenic, and anticarcinogenic effects (Monteiro et al., 2005; Benavente-Garcia et al., 1997; Elangovan et al., 1994; Nkondjock, 2009) can be explained by the presence of bioactive compounds present in medicinal plants. Thus it may be suggested that flavonoids may have a modulating role in the treatment of neurodegenerative diseases due to their phenolic nature, since they can disrupt cellular oxidative processes in the central nervous system (CNS).

Among the activities related to the treatment of neurodegenerative diseases is increasing the search for new inhibitors of acetylcholinesterase activity in extracts and compounds isolated from plants, mainly involving medicinal plants used in traditional medicine as treatment of various pathologies. It is necessary to investigate the effects of active compounds extracted from plants, as these may provide new insights into the clinical treatment of neurodegenerative diseases such as Alzheimer's disease.

Apigenin-7-O-glucopyranoside (ApG) is a flavonoid glycoside isolated from the flowers of Bellis perennis, although its effects on the CNS are yet not determined. Therefore, it would be important to conduct studies in order to clarify its potential antioxidant activity, since the production of free radicals and reactive oxygen derivatives is strongly involved in many physiological and pathological processes including epilepsy, cancer, necrosis, inflammation and pain (Freitas et al., 2004; 2005; 2009; Santos et al., 2010).

In the present study we describe the isolation and identification of the glycosylated flavonoid apigenin-7O-glucopyranoside (ApG) from the flowers of B. perennis, and the evaluation of in vitro antioxidant activity and anticholinesterase activity of the isolated substance. The chemical structure of the substance isolated was defined based on the analysis of ${ }^{1} \mathrm{H}$ NMR and ultraviolet spectroscopic data, and comparison of data obtained with those reported in the literature. We also investigated the antioxidant potential of ApG on the removal of the hydroxyl radical $(\mathrm{OH} \bullet)$, content of nitric oxide (NO) and reactive species with thiobarbituric acid (TBARS), as well as evaluation of acetylcholinesterase in vitro. If these effects are established, it is possible to justify the use of this flavonoid in preclinical and pharmacological models that simulate neurodegenerative diseases.

\section{METHODS}

\section{Plant material}

The studied species, Bellis perennis was collected in October at 07:00 at the farm site São José, in the city of Pacoti in the region 
of Baturité, in the state of Ceará, Brazil. The voucher specimen is deposited in the Herbarium Graziela Barroso (TEBP) at Federal University of Piauí, number TEBP 27,276. Flowers were collected manually, then washed in running water followed by distilled water.

\section{General experimental procedures}

The melting point (m.p.) was determined in a Microchemistry Model APF-301 at a heating rate of $2{ }^{\circ} \mathrm{C} / \mathrm{min}$ and no corrections were made in the values obtained. For chromatographic analysis a photodiode array system of high performance liquid chromatographic detector (HPLCDAD) was used, Model 300 Ultimate (Dionex), coupled to a diode array detector, to an automatic injector, and to column temperature control.

The absorption spectra in the infrared (FTIR) were obtained using a Shimadzu IRAffinity-1 spectrometer, using $\mathrm{KBr}$ pellets. The nuclear magnetic resonance spectra of ${ }^{1} \mathrm{H}$ $\left({ }^{1} \mathrm{H}\right.$ NMR) were recorded on a Varian equipment Model Gemini 2000, operating at $300 \mathrm{MHz}$ and using residual non-deuterated solvent as internal standard, in reference to TMS. The ultraviolet spectra (UV) were recorded on Varian spectrophotometer Model Cary 50, using spectroscopic grade methanol $(\mathrm{MeOH})$ (Tedia Brazil) as solvent.

For adsorption column chromatography (CC) SigmaAldrich $^{\circledR}$ silica gel 60 (60 ̊) was used. The column sizes (length and diameter) varied according to the amount of sample to be chromatographed and the adsorbents. For analytical thin layer chromatography (TLC) Sigma-Aldrich ${ }^{\circledR}$ silica gel 40 (40 Å) was used. The development of compounds was performed by spraying acidic vanillin solution, followed by heating or by exposure to iodine vapors. For elution of the samples the following solvents PA quality $\left(\right.$ Synth $\left.^{\circledR}\right)$ were used: hexane, dichloromethane, chloroform, ethyl acetate and methanol, pure as well as binary mixtures of increasing polarity gradient.

In the procedures of in vitro antioxidant activity and acetylcholinesterase inhibitor a Bioespectro SP-220 (2010) spectrophotometer was used for absorption spectra in the ultraviolet and visible ranges.

\section{Procedure for obtaining extracts and isolating the chemical constituents}

Flowers $(310 \mathrm{~g})$ were separated from the other parts of the plant, dried, statically macerated and subjected to extraction with ethanol at room temperature. The ethanolic extract obtained remained seven days at rest, stirred twice a day, and then was concentrated using a rotary evaporator under reduced pressure to obtain an ethanol extract of flowers (EEF) B. perennis (38 g).

The EEF (38.0 g) was adsorbed onto silica gel and subjected to chromatographic fractionation with hexane, chloroform, ethyl acetate and pure water as eluents, used in order of increasing polarity, yielding the respective mass fractions (7.5 g; $11.5 \mathrm{~g} ; 0.9 \mathrm{~g} ; 4.1 \mathrm{~g}$ ) after distillation of the solvent under reduced pressure. The ethyl acetate fraction was subjected to column chromatography on silica gel using pure eluents and binary mixtures in a gradient of increasing polarity, from which 50 fractions were obtained. After analysis in TLC, hexane $(100 \%)$, hexane:chloroform $(8 / 2,6 / 4,4 / 6,2 / 8)$, chloroform $(100 \%)$, dichloromethane:chloroform $(8 / 2,6 / 4$,
4/6, 2/8), dichloromethane:ethyl acetate $(8 / 2,6 / 4,4 / 6,2 / 8)$, $100 \%$ ethyl acetate and ethyl acetate:methanol $(2 / 8,5 / 5,9 / 1)$, methanol $(100 \%)$ and water were used. The mixtures ethyl acetate:methanol $(2 / 8,5 / 5,8 / 2)$ were pooled because of their similarities; we used fractions 10-12 as ethyl acetate:methanol (5/5). Analysis on CCD acetate/methanol (9/1) recovered the characteristic pure substance $(12 \mathrm{mg})$, which was identified as apigenin 7-O-glucopyranoside by ${ }^{1} \mathrm{H}$ and ${ }^{13} \mathrm{C}$ NMR, FTIR and UV.

\section{Evaluation of antioxidant activity in vitro}

Scavenging activity against the hydroxyl radical

The formation of hydroxyl radical $(\mathrm{OH} \bullet)$ from the Fenton reaction was quantified using oxidative degradation of 2-deoxyribose (Lopes et al., 1999). The principle of the test is to quantify the degradation product of 2-deoxyribose, malonaldehyde (MDA) through its condensation with TBA. Typical reactions were initiated by the addition of $\mathrm{Fe}^{2+}$ (final concentration $6 \mathrm{mmol} / \mathrm{l}$ of $\mathrm{FeSO}_{4}$ ) for solutions containing $5 \mathrm{mmol} / \mathrm{l}$ 2-deoxyribose, $100 \mathrm{mmol} / 1 \mathrm{H}_{2} \mathrm{O}_{2}$ and $20 \mathrm{mmol} / \mathrm{l}$ phosphate buffer (pH 7.4). To measure the ApG antioxidant activity against the hydroxyl radical, different concentrations of ApG $(0.9 ; 1.8 ; 3.6 ; 5.4$ and $7.2 \mu \mathrm{g} / \mathrm{ml})$ were added to the system before addition of $\mathrm{Fe}^{2+}$. Reactions were performed for $15 \mathrm{~min}$ at room temperature and stopped by addition of phosphoric acid at $4 \%(\mathrm{v} / \mathrm{v})$ followed by TBA $(1 \% \mathrm{w} / \mathrm{v}$ in 50 $\mathrm{mmol} / 1 \mathrm{NaOH})$. Solutions were heated in a water bath for $15 \mathrm{~min}$ at $95{ }^{\circ} \mathrm{C}$, and then cooled to room temperature. The absorbance was measured at $532 \mathrm{~nm}$ and the results were expressed as equivalents of MDA formed by $\mathrm{Fe}^{2+}$ and $\mathrm{H}_{2} \mathrm{O}_{2}$. Trolox was used as a standard drug (positive standard); the control received only $0.05 \%$ Tween 80 dissolved in $0.9 \%$ saline and complete degradation of MDA and production of hydroxyl radical.

Assays of reactive species with thiobarbituric acid (TBARS)

TBARS assays were used to quantify lipidic peroxidation (Esterbauer et al., 1990) and to measure the antioxidant capacity of ApG as a substrate, in a medium rich in lipids (Guimarães et al., 2010). Briefly, the adopted lipid-rich substrate to be used was homogenized egg yolk $(1 \% \mathrm{w} / \mathrm{v})$ in $50 \mathrm{mmol} / \mathrm{L}$ phosphate buffer ( $\mathrm{pH} 7.4$ ). A volume of $0.5 \mathrm{ml}$ of homogenate was sonicated and homogenized with $0.1 \mathrm{ml}$ of ApG at different concentrations $(0.9 ; 1.8 ; 3.6,5.4$ and $7.2 \mu \mathrm{g} /$ $\mathrm{ml})$. Lipid peroxidation was induced by adding $0.1 \mathrm{ml} \mathrm{AAPH}$ (2,2 '-azobis [2metilpropionamidina] diidrocloride) (0.12 M). Control received only the control solution $(0.05 \%$ Tween 80 dissolved in $0.9 \%$ saline). Reactions were performed for $30 \mathrm{~min}$ at $37^{\circ} \mathrm{C}$. After cooling, the samples $(0.5 \mathrm{ml})$ were centrifuged in $0.5 \mathrm{ml}$ trichloroacetic acid $(15 \%)$ at $1,200 \mathrm{~g}$ for $10 \mathrm{~min}$. An aliquot of $0.5 \mathrm{ml}$ of supernatant was mixed with $0.5 \mathrm{ml}$ thiobarbituric acid (TBA) $(0.67 \%)$ and heated at $95{ }^{\circ} \mathrm{C}$ for 30 min. After cooling, absorbances of the samples were measured using a spectrophotometer at $532 \mathrm{~nm}$. Results were expressed as percentage of TBARS formed from AAPH only (induced control). Trolox (6-hydroxy-2,5,7,8-tetramethylchroman2-carboxylic acid), a water-soluble derivative of vitamin $\mathrm{E}$ (alpha-tocopherol), an antioxidant substance used in biological 
or biochemical applications to reduce oxidative stress or damages (Lucio et al., 2009), was used as a standard drug.

To evaluate the antioxidant activity of ApG, two other methodologies were adopted which rely on the ability of a substance to sequester free radicals, by direct interaction with molecules of a reactive substance by converting free radicals into less reactive and therefore more stable species (Hoelzl et al., 2005).

Scavenging activity against nitric oxide (NO)

Nitric oxide (NO) was generated from the decomposition of sodium nitroprusside $\left(\mathrm{SNP}, \mathrm{Na}_{2}\left(\left[\mathrm{Fe}(\mathrm{CN})_{5} \mathrm{NO}\right] \cdot 2 \mathrm{H}_{2} \mathrm{O}\right)\right.$ in 20 $\mathrm{mmol} / 1$ phosphate buffer ( $\mathrm{pH} 7.4)$. Once generated, the $\mathrm{NO}$ interacts with oxygen and as a result nitrite is generated (Basu et al., 2006).

The reaction mixture $(1 \mathrm{ml})$ containing $10 \mathrm{mmol} / 1 \mathrm{SNP}$ in phosphate buffer and ApG in different concentrations (0.9; 1.8 ; $3.6 ; 5.4$ and $7.2 \mu \mathrm{g} / \mathrm{ml}$ ) were incubated at $37{ }^{\circ} \mathrm{C}$ for $1 \mathrm{~h}$. An aliquot of $0.5 \mathrm{ml}$ was taken and homogenized with 0.5 $\mathrm{ml}$ Griess reagent. The absorbance of the chromophore was measured at $540 \mathrm{~nm}$. The percentage of inhibition of the nitric oxide generated was measured by comparing the absorbance values of the negative control (only $10 \mathrm{mmol} / 1$ of SNP and control solution) and test preparations. Results were expressed as percentage of SNP only.

In vitro determination of activity of the enzyme acetylcholinesterase

The inhibitory effect of the substance on isolated acetylcholinesterase activity in vitro was evaluated as described by Ellman and collaborators (1961) with some modifications as detailed by Moyo et al. (2010). An NMR spectrometer Varian Cary was used to quantify inhibition activity. Initially, $100 \mu \mathrm{L}$ of the sample (concentrations of $0.0125 \%, 0.00652 \%, 0.003125 \%$ and $0.001563 \%$ in $50 \mathrm{mmol} / 1$ Tris- $\mathrm{HCl}, \mathrm{pH} 8$ buffer solution and $10 \%$ methanol) were mixed with $100 \mu \mathrm{L}$ of AChE $(0.22 \mathrm{U} / \mathrm{ml}$ in $50 \mathrm{mmol} / 1$ Tris- $\mathrm{HCl}$ buffer, $\mathrm{pH} 8,0.1 \% \mathrm{BSA}$ ) and $200 \mu \mathrm{L}$ of buffer $(50 \mathrm{mmol} / 1$ Tris- $\mathrm{HCl}, \mathrm{pH}$ $8,0.1 \%$ BSA). The mixture was incubated for $5 \mathrm{~min}$ at $30{ }^{\circ} \mathrm{C}$. Then $500 \mu \mathrm{L}$ of dithiobisnitrobenzoic acid (DTNB) $(3 \mathrm{mmol} / 1$ Tris- $\mathrm{HCl}, \mathrm{pH} 8,0.1 \mathrm{~mol} / 1 \mathrm{NaCl}, 0.02 \mathrm{~mol} / 1 \mathrm{MgCl}_{2}$ ) and $100 \mathrm{ml}$ of acetylthiocholine iodide (ATCI) $(4 \mathrm{mmol} / 1$ in water) were added.

The blank was studied by sample replacement by $100 \mu \mathrm{L}$ buffer $(50 \mathrm{mmol} / 1$ Tris- $\mathrm{HCl}, \mathrm{pH} 8,0.1 \%$ BSA). The reaction was monitored for $5 \mathrm{~min}$ at $412 \mathrm{~nm}$. The assay is based on spectrophotometric measurement of the increase of the yellow color produced from thiocholine when it reacts with the ion dithiobisnitrobenzoate. The drug rivastigmine (Exelon ${ }^{\circledR}$ ) was used as a standard, and the buffer ( $0.1 \%$ methanol in 50 $\mathrm{mmol} / \mathrm{l}$ Tris- $\mathrm{HCl}, \mathrm{pH} 8,10 \%$ ) was used as negative control. The percentage of inhibition of the isolated substance and of rivastigmine was calculated according to the following equation:

$$
I(\%)=\left[1-\left(\frac{\text { reaction rate of the sample }}{\text { reaction rate of the blank }}\right)\right] * 100
$$

The mean inhibitory concentration values $\left(\mathrm{IC}_{50}\right)$ were obtained by a Log-Probit plot.

\section{Statistical Analysis}

The results were expressed as mean \pm standard error of mean (SEM). To evaluate the significance of differences between means, we used analysis of variance (One-way ANOVA) followed by a post hoc test. Differences between means were considered significant when the value obtained for " $p$ " was less than $0.05(\mathrm{p}<0.05)$. All statistical analysis was performed using the statistical program Graph-PadPrism ${ }^{\odot} 5.01$ (Graph Pad Software, San Diego, CA, USA).

\section{RESULTS}

Isolation of the constituents of the ethanol extracts of flowers (EEF) of Bellis perennis

The literature reveals that the chemical constituents of $B$. perennis (Asteraceae) include saponins, triterpenes, several anthocyanins, flavonoids and polyacetylenes (Li et al., 2004; Morikawa et al., 2010; Masayuki et al., 2010). In the fractionation of the leaves, the following yields were obtained: hexane $(57 \%)$ chloroform $(19 \%)$, ethyl acetate $(0.3 \%)$ and water $(10.85 \%)$. The fraction of ethyl acetate:methanol/water (F-10/12) in the ratio 9:1 after lyophilization yielded $12 \mathrm{mg}$ (yield $=3.5 \%$ ) of a dark yellow viscous liquid, which showed the characteristics of a pure substance in TLC.

Characterization and identification of structural substance of flavonoid isolated from the flowers of Bellis perennis

The sample was purified by HPLC-DAD and then analyzed using FTIR, UV, ${ }^{1} \mathrm{H}$ NMR, ${ }^{13} \mathrm{C}$ NMR, and DEPT 135 NMR spectra with addition of shift reagents; these showed that the fraction consists of a flavone apigenin-labeled glycosylated 7-O-glucopyranoside (1), a yellow solid with m.p. $238{ }^{\circ} \mathrm{C}$ (with decomposition). In the FTIR spectrum only stretch signals of $\mathrm{OH}, \mathrm{C}=\mathrm{O}$ and $\mathrm{CO}$ of alcohols and phenols were recorded. However, analysis of the data obtained in the ${ }^{1} \mathrm{H}$ NMR spectrum (Table I) showed that the fraction consisted of a flavonoid. The presence of two doublets at $7.87 \mathrm{ppm}$ and 6.93 ppm, ${ }^{2} \mathrm{H}$ integrating for each is indicative of the presence of the $\mathrm{B} 1,4$ di-substituted ring.

The resonances occurred between $\delta 6.4$ and 6.8, especially the doublets at $\delta 6.48$ and 6.81 with $\mathrm{J}=2.1 \mathrm{~Hz}$, which are characteristic of the ring hydrogens in 5, 7-O-substituted flavones. In the region of $\delta 3.0$ to 4.2 the presence of several multiplets was verified, indicating the presence of oxyhydrogen methynics and oxy-methylene glycosidic units. It can be concluded that the sugar is linked to flavonoid, due to the signal in the anomeric hydrogen $\delta 5.2$, characteristic of the beta configuration of sugars. Analysis of the NMR data of the ${ }^{13} \mathrm{C}$ fraction (Table 1) confirms the information obtained from the above data. The DEPT-135 spectrum allowed the identification of the multiplicity of each carbon and hence identified the osidic unit substance as glucose.

The position of the flavone glucose can be obtained by comparing the UV spectra of the substance and reagent addition displacement. Addition of a solution of $\mathrm{AlCl}_{3}$ resulted in bathochromic shifting I and II band absorption. This shift was not decomposed by the addition of $\mathrm{HCl}$, suggesting the presence of an $\mathrm{OH}$ group at $\mathrm{C}-5$ and/or C-3 (Fig. 1.1). The addition of $\mathrm{NaOMe}$ solution caused bathochromic 
displacement of $56 \mathrm{~nm}$ in band I absorption without a decrease in intensity over time, suggesting the presence of a free $\mathrm{OH}$ at C-4' (Fig. 1.2). The addition of sodium acetate solution did not cause bathochromic displacement in Band II (268 nm), thereby suggesting the presence of sugar C-7 (Fig. 1.3).

In previous studies with $B$. perennis several flavonoid glycosides were isolated such as rutin, isoramentina 3-O-glicopiranosídeo (Yoshikawa et al., 2008), isorhamnetina 3-O- $\beta$-D-(6"'-acetyl) galactopyranoside and kaempferol-3O- $\beta$-D-glicopyranosideo (Gudej, 2001), including apigenin 7-O-glucopyranoside (1) (Fig. 2).

Apigenin-7-O-glucopyranoside (1) $\left(\mathrm{C}_{21} \mathrm{H}_{20} \mathrm{O}_{10}\right)$

Isolated apigenin was obtained as a yellow amorphous solid, soluble in ethyl acetate/methanol with a retention factor of $R_{f}=0.5$ (ethyl acetate:methanol 1/1) and melting point 238 ${ }^{\circ} \mathrm{C}$; Molecular Weight: 432.38. Ultra-Violet: $1_{\max }(\mathrm{MeOH}) \mathrm{nm}$ : 268, 334; + NaOMe: 267, 390, +: $\mathrm{AlCl}_{3} 276,299,344,384 ;{ }^{1} \mathrm{H}$ and ${ }^{13} \mathrm{C}$ NMR (Table 1), according to the literature (Morikawa et al., 2008).

Determination of in vitro antioxidant activity

The antioxidant activity of ApG was investigated, since there is evidence suggesting that in stressful situations there is a decrease in brain metabolism of free radicals (neutralization of radicals, becoming more stable and less aggressive). Hence, the brain has a specific pathway to metabolize free radicals (Gaté et al., 1999; Mandelker, 2008) which influences the process of

\section{TABLE I}

NMR data of the fraction $10\left[300 \mathrm{MHz}(\mathrm{H}) / 75 \mathrm{MHz}\left({ }^{13} \mathrm{C}\right)\right.$, $\left.\mathrm{MeOH}-\mathrm{d}_{4}, \delta(\mathrm{ppm})\right]$.

\begin{tabular}{llr}
\hline \multicolumn{1}{c}{ Position } & $\delta_{\mathrm{H}}(m, \mathrm{~J}$ in $\mathrm{Hz})$ & \multicolumn{1}{c}{$\delta_{\mathrm{C}}$} \\
\hline 2 & - & 162.9 \\
3 & $6.65(s)$ & 117.5 \\
4 & - & 184.1 \\
5 & - & 164.8 \\
6 & $6.48(d, 2.1)$ & 101.2 \\
7 & - & 166.0 \\
8 & $6.81(d, 2.1)$ & 96.0 \\
9 & - & 165.4 \\
10 & - & 107.1 \\
$1^{\prime}$ & - & 123.0 \\
$2^{\prime}, 6^{\prime}$ & $7.87(d, 8.7)$ & 129.6 \\
$3^{\prime}, 5^{\prime}$ & $6.93(d, 8.7)$ & 117.0 \\
$4^{\prime}$ & - & 158.9 \\
$1^{\prime \prime}$ & $5.07(d, 7.8)$ & $10 ., 6$ \\
$2^{\prime \prime}$ & $3.75-3.4(m)$ & 74.7 \\
$3^{\prime \prime}$ & $3.75-3.4(m)$ & 77.8 \\
$4^{\prime \prime}$ & $3.75-3.4(m)$ & 71.3 \\
$5^{\prime \prime}$ & $3.75-., 4(m)$ & 78.4 \\
$6^{\prime \prime}$ & $3.9-3.5$ & 62.5 \\
\hline
\end{tabular}

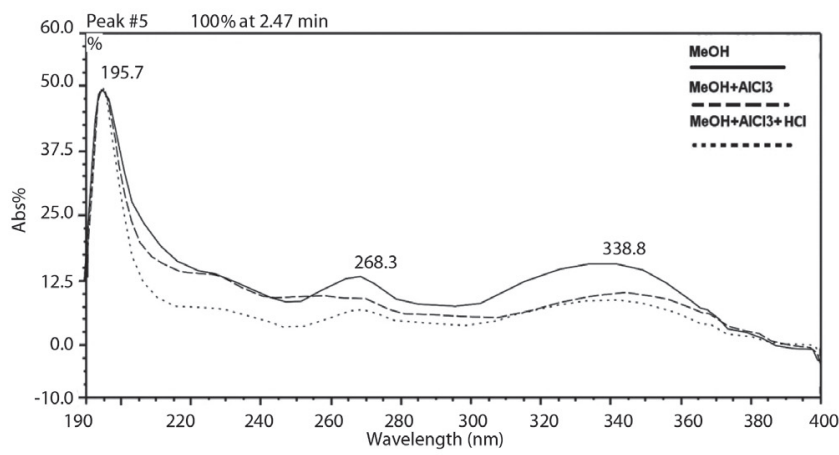

(1.1)

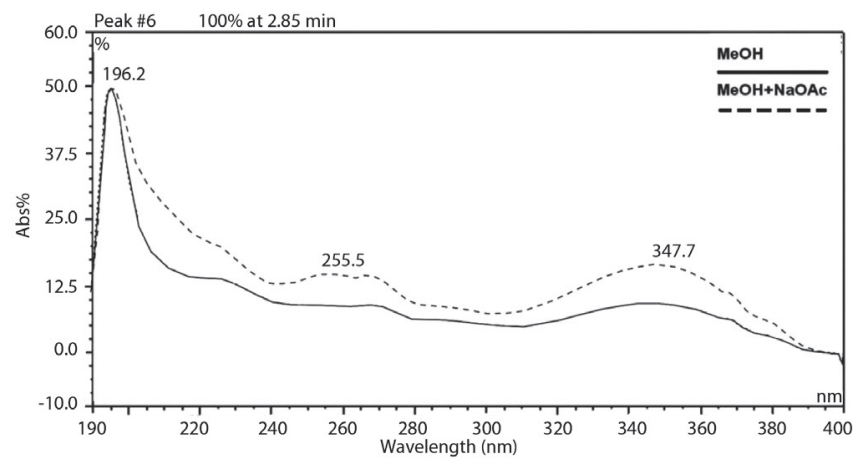

(1.2)

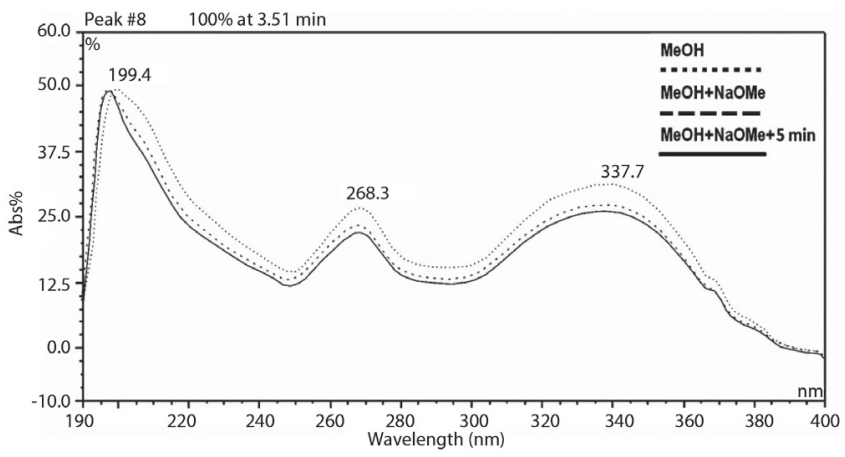

(1.3)

Figure 1. The UV spectra of APG in $\mathrm{MeOH}$, with addition of $\mathrm{AlCl}_{3}$ and $\mathrm{HCl}$. MeOH: $268 \mathrm{~nm}, 334 \mathrm{~nm}$; AlCl3: $276 \mathrm{~nm}, 299 \mathrm{~nm}, 344$ $\mathrm{nm}, 384 \mathrm{~nm}$ (1), with addition of $\mathrm{NaOMe}$. $\mathrm{MeOH}: 268 \mathrm{~nm}, 334$ $\mathrm{nm}$; NaOMe: $267 \mathrm{~nm}, 390 \mathrm{~nm}$ (2) and with addition of NaOMe. MeOH: 268 nm, 334 nm; NaOMe: 267 nm, 390 nm (3).<smiles>O=c1cc(-c2ccc(O)cc2)oc2cc(OC(O)CC(O)C3C(O)CC3O)cc(O)c12</smiles>

Figure 2. Chemical structure of apigenin 7-0-glucopyranoside isolated from ethanolic extract of flowers of $B$. perennis. 
lipid peroxidation (Basu et al., 2006), the content of nitric oxide (Oliveira et al., 2007; Ferreira et al., 2009) and the production of TBARS (Serafini et al., 2011).

At the tested concentrations, ApG was able to remove the $\mathrm{OH} \bullet$ radical significantly, by $68.2,73.5,76.45,77.11$ and $77.68 \%$ compared to the reaction system at concentrations of $0.9,1.8,3 ., ; 5.4$ and $7.2 \mu \mathrm{g} / \mathrm{ml}$, respectively, with $50 \%$ inhibitory concentration $\left(\mathrm{IC}_{50}\right.$ ) equal to $0.43 \mu \mathrm{g} / \mathrm{ml}, 95 \%$ confidence limits 0.27 and $0.66 \mu \mathrm{g} / \mathrm{ml}\left(\mathrm{r}^{2}=0.97\right)$. Likewise, Trolox used as positive standard at a concentration of $0.45 \mathrm{mmol} / 1$ inhibited the production of the hydroxyl radical by $70.51 \% \quad(\mathrm{p}<0.05)$ compared to the reaction medium (Fig. 3).

The TBARS method is used to quantify lipid peroxidation, which is a cell membrane damage caused by oxidative stress. $\mathrm{AAPH}$, a water-soluble azo compound, is used as free radical

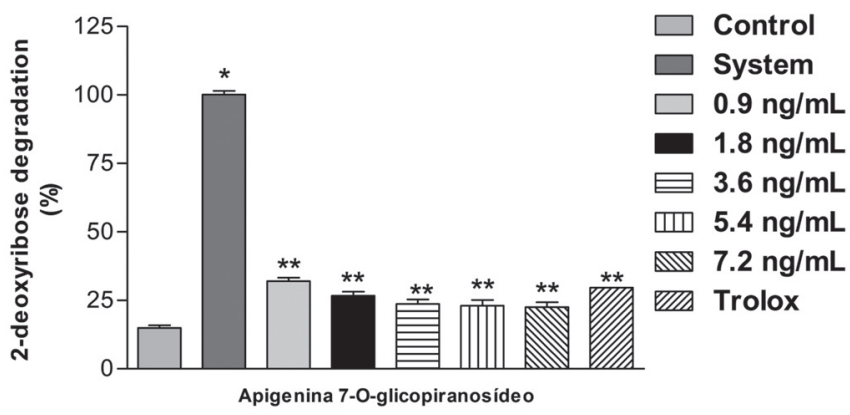

Figure 3. Effect of apigenin 7-O-glucopyranoside in cleaning $\mathrm{OH}$ in vitro. Hydroxyl radical scavenging was quantified using 2-deoxyribose oxidative degradation in vitro, which produces malondialdehyde by condensation with 2-thiobarbituric acid (TBA). The system is MDA production from 2-deoxyribose degradation and $\mathrm{FeSO}_{4}$ with $\mathrm{H}_{2} \mathrm{O}_{2}$ alone, the control was $0.05 \%$ Tween 80 dissolved in $0.9 \%$ saline solution. Other groups denote MDA production of $\mathrm{H}_{2} \mathrm{O}_{2}$ and $\mathrm{FeSO}_{4}$ in the presence of different concentrations of apigenin 7-O-glucopyranoside (0.9 - 1.8 - 3.6 to 5.4 and $7.2 \mu \mathrm{g} / \mathrm{ml})$. Values represent mean \pm S.E.M. $(\mathrm{n}=5)$, experiments in duplicate, ${ }^{*} p<0.001$ versus control and ${ }^{* *} p<0.001$ versus system (ANOVA and post hoc test).

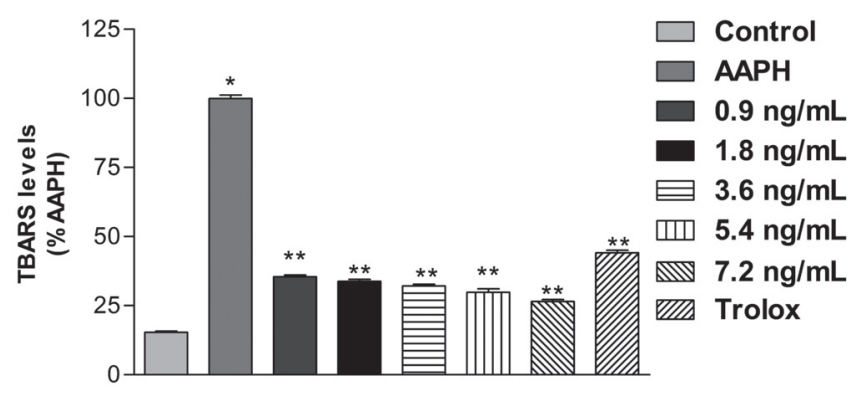

Figure 4. Effects of apigenin 7-O-glucopyranoside on assays of reactive species with thiobarbituric acid in vitro. Lipid extracted from egg yolk was subjected to oxidative damage by incubation with AAPH and the ability of different concentrations of apigenin-7-Oglucopyranoside to prevent the formation of TBARS was analyzed. Control means basal lipid peroxidation with control alone $(0.05 \%$ Tween 80 dissolved in $0.9 \%$ saline solution); AAPH group alone is considered $100 \%$ oxidative damage. Values represent mean \pm SEM $(n=5)$, experiments in duplicate, ${ }^{*} p<0.001$ versus control and ${ }^{* *} \mathrm{p}<0.001$ versus APPH (ANOVA and post hoc test). generator. Its decomposition produces molecular nitrogen and a carbonyl radical, which in turn react with thiobarbituric acid, resulting in the formation of TBARS (Zin et al., 2002; Fitó et al., 2007; Halliwell et al., 2007). The results show that in all tested concentrations $(0.9,1.8,3.6,5.4$ and $7.2 \mu \mathrm{g} / \mathrm{ml})$ ApG caused a significant decrease in TBARS production with respect to the AAPH group, with inhibition of 64, 66, 67.8, 70 and $73.43 \%$, respectively. Trolox (standard drug) also reduced the observed parameter, presenting 55.8\% $[\mathrm{p}<0.001]$ inhibition (Fig. 4), this ApG method showed $\mathrm{IC}_{50}$ equal to $1.62 \mu \mathrm{g} / \mathrm{ml}, 95 \%$ confidence limits 1.13 and $2.35 \mu \mathrm{g} / \mathrm{ml}\left(\mathrm{r}^{2}=0.94\right)$, therefore it demonstrated that ApG can exert antioxidant potential with protective effect for lipid biomolecules (Serafini et al., 2011).

Another methodology employed was the assay for removal of nitric oxide content. The method is based on the production of nitrite ions $\left(\mathrm{NO}_{2}^{-}\right)$from the decomposition of sodium nitroprusside in aqueous solution. The NO interacts with oxygen to produce $\mathrm{NO}_{2}^{-}$, which can be measured by Griess reaction (Basu et al., 2006), according to:

$$
\mathrm{SNP} \rightarrow 2 \mathrm{NO}+\mathrm{O}_{2} \rightarrow 2 \mathrm{NO}_{2}^{-}
$$

Nitric oxide has strong oxidizing power, reacting with various biological molecules, which leads to cell damage where substances with NO-sequestrant action compete with oxygen, leading to reduced production of nitrite, showing the antioxidant activity (Zin et al., 2002; Fitó et al., 2007; Halliwell et al., 2007; Ahmadi et al., 2011; Serafini et al., 2011)

The post hoc test of means indicated a significant decrease of 46 and $34 \%$ of nitrite content in vitro in concentrations 0.9 and $1.8 \mu \mathrm{g} / \mathrm{ml}[\mathrm{p}<0.01]$, compared to SNP, and 53, 59 and $72 \%$ at concentrations of 3.6, 5.4 and $7.2 \mu \mathrm{g} / \mathrm{ml}$, respectively. Trolox produced a significant decrease of $66.35 \%$ [p<0.001] (Fig. 5), with $\mathrm{IC}_{50}$ of $6.97 \mu \mathrm{g} / \mathrm{ml}, 95 \%$ confidence limits 4.1 and $10.9 \mu \mathrm{g} /$ $\mathrm{ml}\left(\mathrm{r}^{2}=0.81\right)$.

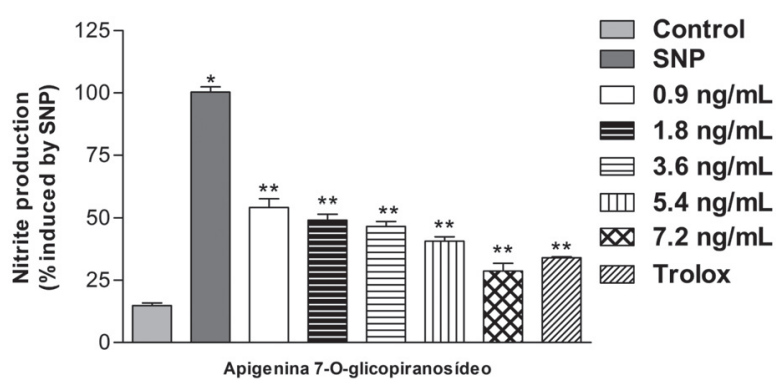

Figure 5. Activity of apigenin 7-O-glucopyranoside in the removal of oxide nitric. Means for controlling the production of NO basal control (0.05\% Tween 80 dissolved in $0.9 \%$ saline) in the absence of a source of NO generator (without SNP); SNP group reflects production of nitrite by sodium nitroprusside alone, considered $100 \%$ of production of NO. The effect of different concentrations of SNP against ApG was determined by the Griess method. Values represent mean \pm SEM $(n=5)$, experiments in duplicate. ${ }^{*} \mathrm{p}<0.001$ versus control and ${ }^{* *} \mathrm{p}<0.001$ versus SNP (ANOVA and post hoc test). 
Determination of in vitro anticholinesterase activity of $A p G$

In vitro studies indicated that there was $92.02 \%$ inhibition of AChE activity when Neostigmine (Exelon ${ }^{\circledR}$ ) was used as positive control at a concentration of $0.1 \%$. Isolated ApG at concentrations of $0.1,0.05,0.0125$ and $0.00625 \%$ showed inhibition of $76.86,54.78,49.46$ and $47.87 \%$ in the activity of AChE, respectively. The $50 \%$ inhibitory concentration $\left(\mathrm{IC}_{50}\right)$ was also determined, which corresponded to $1.91 \mu \mathrm{mol} / \mathrm{l}$, with $95 \%$ confidence intervals of 0.53 and $3.42 \mu \mathrm{mol} / 1\left(\mathrm{r}^{2}=\right.$ 0.8332).

\section{DISCUSSION}

Based on the procedures used in vitro, it was shown that ApG was able to reduce the production of free radicals and this activity can be attributed to its structural feature, since ApG is a flavonoid glycoside; phenols and polyphenols exert their effects through diverse protection mechanisms, such as the blockage that may interfere with or suppress the activity of enzymes involved in the generation of reactive species of oxygen and free radicals, chelating transition metals to inactive species (Wong et al., 2006) Its antioxidant properties can be related to the hydroxyl group $(\mathrm{OH})$ present in the molecule. ApG, the flavonoids and isoflavonoids are probably electron donors; they have a $\beta$ ring conjugated chemical structures rich in hydroxyl groups, which have potential antioxidant actions by reacting with and inactivating superoxide anions, oxygen lipid peroxide radicals and/or stabilizing free radicals involved in the oxidative process by hydrogenation or complexing with oxidant species (Birt et al., 2001, Wong et al., 2006), according to:

$$
\text { Flavonoid }(\mathrm{OH})+\mathrm{R} \bullet \rightarrow \text { Flavonoid }(\mathrm{O} \bullet)+\mathrm{RH}
$$

A widely used methodology to evaluate the antioxidant activity of a substance is based on the capability of removing free radicals formed in less reactive species (Hoelzl et al., 2005). The ability of a substance to remove the hydroxyl radical is directly related to its antioxidant activity. In this method, the $\mathrm{OH} \bullet$ is generated by the Fenton reaction. In the presence of the hydroxyl radical, the deoxyribose is degraded to malonaldehyde and quantified (Páya et al., 1992; Huang et al., 2005; Serafini et al., 2011). This study demonstrated that ApG produced significant removal of $\mathrm{OH} \bullet$, displaying a considerable antioxidant activity, which may be capable of inhibiting cell damage caused by this radical. Trolox (standard) also significantly reduced the amount of the radical. However, this method has a drawback because many antioxidants also have the property of chelating metals. Thus, it is impossible to distinguish whether the action of the substance was to remove the $\mathrm{OH} \bullet$ radical or simply a chelating effect (Huang et al., 2005).

ApG exhibited significant activity in the removal of hydroxyl radical $\mathrm{OH} \bullet$ present in the reaction medium, suggesting that this effect may be due to antioxidant activity. Thus the data suggest a possible capacity of cellular protection against damage to protein biomolecules in vivo that needs to be investigated further. Our compound has antioxidant properties similar to uguenenprenol and 7-O- methylaromadenrin against removal of the hydroxyl radical in vitro. On the other hand, compounds 11a and the elemodiol furoquinoline skimmianine alkaloids demonstrated lower antioxidant capacity at all concentrations tested in vitro (Kiplimo et al., 2012).

ApG significantly decreased the production of nitrite, again demonstrating its antioxidant properties against damage caused by free radicals; therefore it is possible that ApG produces a more stable interaction with specific types of lipids. In a system rich in lipids such as a lipid TBARS assay, with lower affinity for hydrophilic portions of amphipathic lipids, they are more susceptible to damage caused by radicals, allowing the start of the chain reaction of lipid peroxidation (Guimarães et al., 2010).

These results suggest that the protection against chain reactions of lipid peroxidation, observed in the TBARS assay, is probably due to interaction of components of ApG with hydroxyl radicals which are derived reactive oxygen species (ROS), instead of $\mathrm{NO}_{2}^{-}$which is a derived reactive nitrogen species (RNS). Although ApG has shown an effect in the removal of $\mathrm{NO}_{2}^{-}$at certain concentrations, some of its components will likely increase production of $\mathrm{NO}_{2}^{-}$when present in higher concentrations or cancel this effect against $\mathrm{NO}_{2}{ }^{-}$at lower concentrations of ApG. Compared to other studies (Park et al., 2006 and Yi et al., 2008), the compound evaluated presents a better effect against the formation of ERNS.

In assay with various substances for in vitro determination of acetylcholinesterase activity, the values were evaluated for the $50 \%$ inhibitory concentration $\left(\mathrm{IC}_{50}\right)$ of two pure flavonoids mentioned in the literature as inhibitors of AChE, quercetin (Orhana et al., 2007; Khan et al., 2009) and macluraxanthone (Khan et al., 2009) that inhibited the enzyme with $\mathrm{IC}_{50}$ values of 353.86 and $8.47 \mu \mathrm{mol} / \mathrm{l}$, representing a $76.2 \%$ inhibitory effect against AChE.

ApG showed an $\mathrm{IC}_{50}$ value of $1.91 \mu \mathrm{mol} / \mathrm{l}$, a value that is close to the range of $\mathrm{IC}_{50}$ values found in the literature for galanthamine $(0.39$ to $1.5 \mu \mathrm{mol} / 1)$, a substance of natural origin used for the treatment of Alzheimer's disease (Hillhouse et al., 2004; Kisslinget al., 2005; Adsersen et al., 2006).

Several studies have demonstrated a possible action of flavonoids as antioxidants, and it is established that the mechanism of action is based on the modulation of important intracellular signal pathways for cell function. Furthermore, a glicidic portion of the molecule is required for AChE inhibition (Fan et al., 2008). Its low toxicity and high accessibility have proven to be the most favorable path in obtaining biologically active compounds to prevent and treat damage caused by oxidative stress (Gomes et al., 2008). The enzyme inhibited by these compounds can be unstable, and its regeneration is relatively fast compared to other compounds, so that the compound can enhance cholinergic stimulation more effectively.

Given the results, this study will contribute to future investigations on bioactive molecules such as apigenin 7-O-glucopyranoside, originated from a natural compound that has shown promising results in in vitro antioxidant tests that need to be explored in vivo, to justify its possible use in pharmacological tests that simulate disease for its antioxidant properties observed in vitro. More studies are necessary to elucidate the possible mechanisms of antioxidant action, which could be used, after further research, to formulate pharmaceutical products for the prevention and/or treatment of Alzheimer's pathology, associated with reduced cerebral neurotransmitters, especially acetylcholine. 


\section{ACKNOWLEDGMENT}

The authors thank the National Council for Scientific and Technological Development (CNPq/Brazil) and the Research Supporting Foundation of State of Piaui (FAPEPI/Brazil) for financial support.

\section{REFERENCES}

ADSERSEN A, GAUGUIN B, GUDIKSEN L, JAGER AK (2006) Screening of plants used in Danish folk medicine to treat memory dysfunction for acetylcholinesterase inhibitory activity. J Ethnopharmacol 104:418-422.

AHMADI A, EBRAHIMZADEH MA, ASHRAfiA SA, KARAMI M, MAHDAVI MR, SARAVI SSS (2011) Hepatoprotective, antinociceptive and antioxidant activities of cimetidine, ranitidine and famotidine as histamine $\mathrm{H}_{2}$ receptor antagonists. Fund Clin Pharmacol 25:72-79.

AVATO P, TAVA A, (1995) Acetylenes and Terpenoids of Bellis perennis. Phytochem 40:141-147.

BASU S, HAZRA B (2006) Evaluation of nitric oxide scavenging activity, in vitro and ex vivo, of selected medicinal plants traditionally used in inflammatory diseases. Phytotherapy Res 20:896-900.

BENAVENTE-GARCIA O, CASTILLO J, MARIN FR, ORTUÑO A, DEL RIO JA (1997) Uses and properties of Citrus flavonoids. J Agric Food Chem 45:4505-4515.

BIRT D F, HENDRICH S, WANG W (2001) Dietary agents in cancer prevention: flavonóides and isoflavonoids. Pharmacol Ther 90:157-177.

ELANGOVAN V, SEKAR N, GOVINDASAMY S (1994) Chemoprotective potential of dietary bioflavonoids aginst 20-methyl-chloranthreneinduced tumorogenesis. Cancer Lett 87:107-113.

ELLMAN GL, COURTNEY D K, ANDRES VJ, FEATHERSTONE RM (1961) A new and rapid colorimetric determination of acetylcholinesterase activity. Biochem Pharmacol 7:88-95.

ESTERBAUER H, CHEESEMAN KH (1990) Determination of aldehydic lipid peroxidation products: malonaldehyde and 4-hydroxynonenal. Meth Enzymol 186:407-421.

FAN P, HAY AE, MARSTON A, HOSTETTMANN K (2008) Acetylcholinesterase inhibitory activity of linarin of Buddleja davidii, structure-activity relationships of flavonoids related and research chemicals Buddleja clear. Pharm Biol 46:596-601.

FERREIRA PMP, MILITÃO GCG, FREITAS RM (2009) Lipoic acid effects on lipid peroxidation level, superoxide dismutase activity and monoamines concentration in rat hippocampus. Neurosci Lett 464:131-134.

FITÓ M, TORRE R, COVAS MI (2007) Olive oil and oxidative stress. Mol Nutr Food Res 51:1215-1224.

FREITAS RM (2009) The evaluation of effects of lipoic acid on the lipid peroxidation, nitrite formation and antioxidant enzymes in the hippocampus of rats after pilocarpine-induced seizures. Neurosc Lett 455:140-144.

FREITAS RM, VASCONCELOS SM, SOUZA FC, VIANA GS, FONTELES M (2005) Oxidative stress in the hippocampus after status epilepticus in rats. FEBS J 272:1307-1312.

FREITAS RM, VIANA GSB, SOUZA FCF, FONTELES MMF, VASCONCELOS SMM (2004) Pilocarpine-induced status epilepticus in rats: lipid peroxidation level, nitrite formation, GABAergic and glutamatergic receptor alterations in the hippocampus, striatum and frontal cortex. Pharmacol Biochem Behavior 78:327-332.

GATÉ L, PAUL J, BA GN, TEW KD, TAPIERO H (1990) Oxidative stress induced in pathologies: the role of oxidants. Biomed Pharmacother 53:169-180.

GOMES PB, NORONHA EC, MELO CT, BEZERRA JN, NETO MA, LINO CS, VASCONCELOS SM, VIANA GS, SOUSA FC (2008) Central effects of isolated fractions from the root of Petiveria alliacea L. (tipi) in mice. J Ethnopharmacol 120:209-214.

GUDEJ J, NAZARUK J (2001) Flavonol glycosides from the flowers of Bellis perennis. Fitoterapia 72:839-840.

GUIMARÃES AG, OLIVEIRA GF, MELO MS, CAVALCANTI SC, ANTONIOLLI AR, BONJARDIM LR, SILVA FA, SANTOS JPA, ROCHA RF, MOREIRA JCF, ARAÚJO AA, GELAINN DP,

HALLIWELL B, GUTTERIDGE JMC (2007) Free Radicals in Biology and Medicine. (eds) $4^{\mathrm{a}}$ ed Oxford University Press, New York

HILLHOUSE BJ, MING DS, FRENCH CJ, TOWERS GHN (2004) Acetylcholine esterase inhibitors in Rhodiola rosea. Pharm Biol 42:68-72.

HOELZL C, BICHLER J, FERK F, SIMIC T, NERSESYAN A, ELBLING L, EHRLICH V, CHAKRABORTY A, KNASMULLER S (2005) Methods for the detection of antioxidants which prevent age related diseases: a critical review with particular emphasis on human intervention studies. J physic pharm 56:49-64.

HUANG D, OU B, PRIOR R (2005) The chemistry behind antioxidant capacity assays. J Agric Food Chem 53:1841-1856.

JUDD WS, CAMPBELL CS, KELLOGG EA, STEVENS PF, DONOGHUE MJ (2009) Sistemática Vegetal: um enfoque filogenético. (eds) $3^{\mathrm{a}}$ ed Artmed:Porto Alegre.

KAVALCIOĞLU N, AÇIK L, DEMIRCI F, DEMIRCI B, DEMIR H, BASER KH (2010) Biological activities of Bellis perennis volatiles and extracts. Nat Prod Commun 5:147-150.

KHAN MTH, ORHAN I, ŞENOL FS, KARTAL M, ŞENER B, DVORSKÁ M, ŠMEJKAL K, ŠLAPETOVÁ T (2009) Cholinesterase inhibitory activities of some flavonoid derivatives and chosen xanthone and their molecular docking studies. Chem Biol Interactions 181:383-389.

LUCIO M, NUNES C, GASPAR D, FERREIRA H, LIMA JLFC, REIS S (2009) Food Biophysics 4:312-320.

PARK KH, PARK YD, HAN JM, IM KR, LEE BW, JEONG IY JEONG, TS, LEE WS (2006) Anti-atherosclerotic and anti-inflammatory activities of catecholic xanthones and flavonoids isolated from Cudrania tricuspidata. Bioorganic \& Amp Med Chem Lett 16:5580-5583.

KIPLIMO JJ, ISLAM MS, KOORBANALLY NA (2012) Ring A-seco limonoids and flavonoids from the Kenyan Vepris uguenensis Engl. and their antioxidant activity. Phytochem 83:136-43.

KISSLING J, IOSET JR, MARSTON A, HOSTETTMANN K (2005) Bioguided isolation of cholinesterase inhibitors from the bulbs of Crinum $x$ powellii. Phytother Res 19:984-987.

LI W, ASADA Y, KOIKE K, NIKAIDO T, FURUYA T, YOSHIKAWA T, BELLISOSIDES AF (2005) six novel acylated triterpenoid saponins from Bellis perennis (Compositae). Tetrahedron 61:2921-2929.

LOPES GK, SCHULMAN HM, HERMES-LIMA M (1999) Polyphenol tannic acid inhibits hydroxyl radical formation from Fenton reaction by complexing ferrous ions. Biochimica et Biophysica Acta (BBA) - General Subjects 1472:142-152.

LUBIAN CT, TEIXEIRA JM, LUND RG, NASCENTE PS, DEL PINO, FAB (2010) Atividade antifúngica do extrato aquoso de Arctium minus (Hill) Bernh. (Asteraceae) sobre espécies orais de Cândida. Rev Bras Plantas Med 12:157-162.

MANDELKER L (2008) Cellular effects of comom atioxidants. Vet Clin North Am Small Anim Pract 38:199-211.

MARQUES THC, CARDOSO KMF, ALMEIDA AAC, TOMÉ AR, FREITAS RM (2011) Estudos comportamentais e das alterações histopatológicas em camundongos pré-tratados com Bellis perennis no modelo de convulsão induzido por pilocarpina. Bol Latinoam Caribe Plant Med Aromat 10:338-350.

MONTEIRO MC, TRUGO LC (2005) Determinação de compostos bioativos em amostras comerciais de café torrado. Quim Nova 28:637-41.

MORIKAWA T, LI X, NISHIDA E, NAKAMURA S, NINOMIYA $\mathrm{K}$, MATSUDA $\mathrm{H}$, ODA Y, MURAOKA O, YOSHIKAWA M (2008) Perennisosides I-VII, Acylated Triterpene Saponins with Antihyperlipidemic Activities from the Flowers of Bellis perennis. J Nat Prod 71: 828-835.

MORIKAWA T, LI $X$, NISHIDA E, NAKAMURA S, NINOMIYA K, MATSUDA H, ODA Y, MURAOKA O, YOSHIKAWA M. (2010) Medicinal Flowers. Part 29. Acylated Oleanane-Type Triterpene Bisdesmosides: Perennisaponins G, H, I, J, K, L, and M with Pancreatic Lipase Inhibitory Activity from the Flowers of Bellis perennis. Helv Chim Acta 93:573-586.

MOYO M, NDHLALA AR, FINNIE JF, VAN STADEN J (2010) Phenolic composition, antioxidant and acetylcholinesterase inhibitory activities of Sclerocarya birrea and Harpephyllum caffrum (Anacardiaceae) extracts. Food Chem 123:69-76.

NKONDJOCK A (2009) Coffee consumption and the risk of cancer: An overview, Cancer Lett 277:121-125.

OBERBAUM M, GALOYAN N, LERNER-GEVA L, SINGER R, GRISARU S, SHASHAR D, SAMUELOFF A (2005) The effect of the homeopathic remedies Arnica montana and Bellis perennis on mild postpartum bleeding - A randomized, double-blind, placebo-controlled study Preliminary results. Complement Ther Med 13:87-90.

OLIVEIRA AA, ALMEIDA JP, FREITAS RM, NASCIMENTO VS, AGUIAR LM, JÚNIOR HV, FONSECA FN, VIANA GS, SOUSA FC, FONTELES MM (2007) Effects of levetiracetam in lipid peroxidation level, nitritenitrate formation and antioxidant enzymatic activity in mice brain after pilocarpine-induced seizures. Cell Mol Neurobiol 27:395-406. 
ORHANA I, KARTALB M, TOSUNA F, SENER BZ (2007)Screening of Various Phenolic Acids and Flavonoid Derivatives for their Anticholinesterase Potential Naturforsch 62:829.

PAYÁ M, HALLIWELL B, HOULT JRS (1992) Interactions of a series of coumarins with reactive oxygen species: Scavenging of superoxide, hypochlorous acid and hydroxyl radicals. Biochem Pharmacol 44:205-214.

SANTOS IMS, FREITAS RLM, SILVA EP, FEITOSA CM, SALDANHA GB, SOUZA GF, TOMÉ AR, FENG D, FREITAS RM (2010) Effects of ubiquinone on hydroperoxide concentration and antioxidant enzymatic activities in the rat hippocampus during pilocarpine-induced seizures. Brain Research 1315:33-40.

SERAFINI MR, SANTOS RC, GUIMARÃES AG, SANTOS JPA, SANTOS ADC, ALVES IA, GELAIN DP, NOGUEIRA PCL, QUINTANS-JÚNIOR LJ, BONJARDIM LR, ARAÚJO AAS (2011) Morinda citrifolia Linn leaf extract possesses antioxidant activities and reduces nociceptive behavior and leukocyte migration. J Med Food 14:1159-1166.
WONG C, LI H, CHENG K, CHEN F (2006) A systematic survey of antioxidant activity of 30 Chinese medicinal plants using the ferric reducing antioxidant power assay. Food Chem 97:705-711.

YI Z, YU Y, LIANG YZ, ZENG B (2008) In vitro antioxidant and antimicrobial activities of the extract of Pericarpium Citri Reticulatae of a new Citrus cultivar and its main flavonoids. LWT - Food Science and Technology 41:597-60.

YOSHIKAWA M, LI X, NISHIDA E, NAKAMURA S, MATSUDA H, MURAOKA O, MORIKAWA T (2008) Medicinal flowers. XXI. Structures of perennisaponins A, B, C, D, E, and F, acylated oleanane-type triterpene oligoglycosides, from the flowers of Bellis perennis. Chem Pharm Bulletin 56:559.

ZIN ZM, ABDUL-HAMID A, OSMAN A (2002) Antioxidative activity of extracts from Mengkudu (Morinda citrifolia L.) root, fruit and leaf. Food Chem 78:227-231. 